\title{
AN OVERVIEW OF VOLUNTARY PRIVATE PENSION FUNDS IN TURKEY
}

\section{TÜRKIYYE’DE BİREYSEL EMEKLIILİK FONLARINA GENEL BİR BAKIṢ}

\author{
Fatih KAYHAN* iD \\ Asli TOGAN EGRİCAN ${ }^{* *}$ (iD
}

\begin{abstract}
We provide an overview of the voluntary pension fund market in Turkey by starting with recent developments in the global pension markets and then focusing on the pension fund reform in Turkey and the following developments since 2003. Findings from the literature indicate that the reforms on the introduction of voluntary pension funds in Turkey have positive implications for the overall national savings rates and capital market development. Voluntary pension funds create extra income for beneficiaries after their retirement. However, redesigning the system in a simplified structure is necessary in order to increase participation, inclusion and also to ensure persistency.
\end{abstract}

Keywords: Pension Funds, Retirement, Developing Countries, Turkey

JEL classification: G15, G23, H55, J32

Öz

Bu çalışmada, küresel emeklilik piyasalarındaki son gelişmeler ve Türkiye’de bireysel emeklilik reformu ile 2003 yılı sonrası gelişmeler üzerine odaklanılarak bireysel emeklilik fonları piyasası (gönüllü Bireysel Emeklilik Sistemi kapsamında) genel olarak değerlendirilmiştir. Literatür incelemesi bulguları göstermiştir ki Türkiye'de gönüllü bireysel emeklilik (sistemi) fonlarının ortaya çıkışı, toplam tasarruf oranı ve sermaye piyasası gelişimini olumlu etkilemiştir. Bireysel emeklilik fonları, müşterileri için emeklilik sonrasında ek gelir imkanı sunarlar. Gönüllü bireysel emeklilik sistemine katılımın artması ve sistemde kalma süresinin anlamlı derecede artırılabilmesini temin etmek için, mevcut sistemin daha sadeleşmiş olarak yeniden inşa edilmesi gerekli görülmektedir.

Anahtar Kelimeler: Emeklilik Fonları, Emeklilik, Gelişmekte Olan Ülkeler, Türkiye

JEL Sinıflaması: G15, G23, H55, J32

* PhD, Kirklareli University, Faculty of Applied Sciences (previously Deputy Fund Manager at MetLife Turkey), fatih.kayhan@klu.edu.tr, Orcid No: 0000-0001-7844-8663.

** PhD, Kadir Has University, Faculty of Management, asli.togan@khas.edu.tr, Orcid No: 0000-0003-0489-6855. We thank seminar participants at Kadir Has University, Mutlu Ozcan, Devrim Alcin Korkut, Cagatay Piskin and two anonymous referees for their comments and suggestions. 


\section{Introduction}

For many economies, whether developed or developing, finding ways to save for retirement remains a challenge, especially as the ratio of actively employed contributors to retired beneficiaries are decreasing and the lifespan of individuals is getting longer. Pension funds are considered to be an important part of the retirement system as they are an important channel for enabling individuals to save for retirement as well as encouraging and increasing long-term investment (Thomas, Spataro and Mathew, 2014; Stewart, Despalins, Remizova, 2014).

Mainly because of demographic shifts towards an ageing population and the burden that retirement plans bring to governments, starting with Chile in 1981 and followed by many others, countries started to reform their pension structure. It is argued that one key motivation for countries to reform their pension systems is the expectation to achieve a capital market oriented system where pension funds will play a role by increasing private sector savings, encouraging long-term investment and reducing the cost of capital for corporations (Vittas, 1995; Raddatz and Schmukler, 2008; Enache, Milos and Milos, 2015).

With respect to the pension reforms, starting in 2001, and going into effect in 2003, Turkey introduced a voluntary private pension system. In addition, taking effect in 2013 , the government announced its state contribution program to participants. Our aim in this paper is to provide an overview of the developments that lead to the voluntary private pension system in Turkey and its current status.

The paper proceeds as follows. In Section I, we first provide an overview of Turkey's capital market reforms, describe the pension systems in general, and then describe the pension system in Turkey in detail. Section II provides an overview of the literature and the last section concludes.

\section{Turkey's Capital Markets and Pension Systems Overview}

Within the past two decades, Turkey has experienced macroeconomic and political volatility and went through four major financial crisis/economic contraction periods (1994, 1999, 2001 and 20082009) (Comert and Yeldan, 2018; the World Bank, 2020). However, there have been significant reforms to increase transparency and improve the depth and liquidity of capital markets. After the major financial crisis of 2001, the International Monetary Fund (IMF) program and the negotiations with the European Union resulted in a massive capital influx to Turkey. During this time period, many financial sector reforms also took place. As part of these financial sector reforms, starting in 2001 , and going into effect in 2003, Turkey introduced a voluntary private pension system. In addition, taking effect in 2013, the government announced its state contribution program to participants. Below, we summarize the national pension systems in general and then focus on Turkey's voluntary pension system in detail.

\section{National Pension Systems}

In general, most national pension systems are a combination of defined benefit (DB) and defined contribution (DC) plans; and they combine elements of 'Pay as You Go' (PAYG), funded, public and private elements. For instance, public pensions have typically been DB in nature and financed on a 
PAYG basis. Increased longevity and the declining ratio of actively employed contributors to retired beneficiaries are threatening the financial sustainability of PAYG DB public systems. (OECD, 2018).

Around the world, large amounts have been allocated in pension plans to finance future pension benefits. As of the end of 2018, globally, pension assets reached \$ 44.1 trillion, despite a slight decrease relative to end-2017 (OECD, 2019). This long-term trend is attributable to positive real net returns over the long term, and to an increase in contributions paid as more people are being covered by a pension plan in a number of countries, especially in those with recent mandatory or auto-enrolment programs. Table 1 below provides information on the amount of assets in pension funds for each country and OECD total between 2005 and 2019.

Table 1: Pension Assets as a Percent of GDP (OECD Countries) 2005-2019

\begin{tabular}{|c|c|c|c|c|c|c|c|c|c|c|c|c|c|c|c|}
\hline Country & 2005 & 2006 & 2007 & 2008 & 2009 & 2010 & 2011 & 2012 & 2013 & 2014 & 2015 & 2016 & 2017 & 2018 & 2019* \\
\hline Australia & 78.0 & 87.2 & 106.0 & 93.4 & 82.1 & 89.0 & 91.9 & 90.5 & 101.2 & 108.6 & 118.2 & 120.9 & 132.4 & 137.9 & 132.0 \\
\hline Austria & 4.6 & 4.8 & 4.6 & 4.3 & 4.9 & 5.1 & 4.8 & 5.1 & 5.6 & 5.8 & 6.0 & 5.9 & 6.0 & 5.6 & 6.1 \\
\hline Belgium & 4.3 & 4.1 & 4.3 & 3.2 & 4.0 & 3.6 & 4.1 & 4.5 & 5.0 & 5.7 & 5.9 & 6.8 & 7.8 & 6.8 & 8.4 \\
\hline Canada & 56.3 & 61.2 & 60.5 & 49.8 & 58.6 & 62.9 & 61.7 & 65.3 & 70.5 & 75.5 & 83.1 & 85.4 & 86.1 & 84.4 & 89.1 \\
\hline Chile & 55.7 & 57.5 & 60.8 & 49.8 & 61.8 & 62.3 & 57.7 & 59.7 & 61.9 & 67.6 & 68.6 & 68.7 & 71.9 & 70.2 & 80.8 \\
\hline Colombia & 11.5 & 11.4 & 15.2 & 14.5 & 13.4 & 16.2 & 17.0 & 18.2 & 18.0 & 20.0 & 20.3 & 22.4 & 25.1 & 24.0 & 26.0 \\
\hline Czech Republic & 3.8 & 4.2 & 4.4 & 4.8 & 5.5 & 5.9 & 6.1 & 6.7 & 7.3 & 7.9 & 8.1 & 8.4 & 8.8 & 9.2 & 9.0 \\
\hline Denmark & 32.9 & 31.6 & 31.6 & 45.8 & 41.7 & 47.9 & 48.1 & 48.2 & 41.1 & 47.1 & 43.7 & 46.5 & 45.7 & 45.3 & 48.7 \\
\hline Estonia & 2.6 & 3.5 & 4.4 & 4.5 & 6.7 & 7.3 & 6.8 & 8.3 & 9.4 & 11.0 & 12.7 & 14.3 & 15.4 & 15.4 & 17.0 \\
\hline Finland & 65.7 & 69.0 & 68.1 & 58.2 & 73.5 & 79.1 & 42.4 & 45.4 & 48.4 & 50.7 & 49.2 & 51.0 & 52.4 & 49.7 & 49.4 \\
\hline France & 0.0 & 0.0 & 0.1 & 0.1 & 0.2 & 0.2 & 0.2 & 0.3 & 0.4 & 0.5 & 0.6 & 0.6 & 0.7 & 0.7 & 0.8 \\
\hline Germany & 4.1 & 4.2 & 4.6 & 4.6 & 5.3 & 5.4 & 5.5 & 6.1 & 6.1 & 6.6 & 6.6 & 6.8 & 6.9 & 6.9 & 7.4 \\
\hline Greece & & & 0.0 & 0.0 & 0.0 & 0.0 & 0.0 & 0.0 & 0.5 & 0.6 & 0.6 & 0.7 & 0.7 & 0.7 & 0.8 \\
\hline Hungary & 8.3 & 9.5 & 10.8 & 9.4 & 12.9 & 14.6 & 3.7 & 3.9 & 3.9 & 4.0 & 4.0 & 4.2 & 4.3 & 3.9 & 3.8 \\
\hline Iceland & 113.5 & 123.7 & 122.1 & 106.3 & 112.4 & 117.8 & 122.2 & 131.5 & 136.8 & 140.7 & 142.8 & 138.3 & 151.5 & 151.2 & 167.6 \\
\hline Ireland & 45.8 & 47.4 & 43.9 & 33.8 & 42.4 & 45.0 & 42.3 & 46.0 & 50.9 & 55.3 & 40.8 & 35.5 & 33.7 & 31.9 & 36.0 \\
\hline Israel & 29.5 & 29.3 & 30.4 & 39.5 & 43.7 & 45.5 & 45.9 & 48.7 & 50.1 & 53.8 & 53.7 & 55.2 & 57.6 & 56.2 & 63.8 \\
\hline Italy & 2.7 & 2.9 & 3.1 & 3.3 & 4.0 & 4.4 & 4.7 & 5.4 & 6.0 & 6.6 & 6.8 & 7.3 & 7.6 & 7.6 & 8.4 \\
\hline Japan & 6.3 & & & & & & 16.9 & 16.9 & 18.2 & 20.4 & 21.1 & 20.4 & 20.7 & & 28.4 \\
\hline Korea & 1.6 & 2.6 & 2.7 & 2.8 & 3.3 & 3.7 & 4.1 & 4.9 & 6.0 & 7.3 & 8.2 & 9.0 & 9.8 & 10.7 & 11.6 \\
\hline Latvia & 0.4 & 0.4 & 0.4 & 0.4 & 0.7 & 0.9 & 0.8 & 0.9 & 1.0 & 1.2 & 1.4 & 1.5 & 1.6 & 1.6 & 1.8 \\
\hline Lithuania & & & & & & 4.0 & 3.9 & 4.3 & 4.6 & 5.2 & 5.8 & 6.6 & 7.1 & 7.2 & 8.3 \\
\hline Luxembourg & 1.1 & 1.0 & 1.0 & 1.0 & 2.3 & 2.0 & 1.9 & 2.0 & 2.1 & 3.0 & 2.8 & 3.0 & 2.9 & 2.7 & 2.9 \\
\hline Mexico & 8.7 & 9.9 & 9.8 & 10.0 & 11.6 & 12.5 & 12.6 & 13.9 & 14.6 & 15.3 & 15.2 & 15.0 & 15.7 & 15.2 & 17.5 \\
\hline Netherlands & 112.5 & 114.9 & 124.8 & 103.6 & 108.8 & 118.9 & 125.4 & 142.7 & 146.6 & 157.2 & 168.6 & 182.2 & 184.3 & 173.3 & 191.4 \\
\hline New Zealand & 11.4 & 12.4 & 11.5 & 10.4 & 11.6 & 14.0 & 15.4 & 16.3 & 18.6 & 21.4 & 22.8 & 24.1 & 26.7 & 27.4 & 31.1 \\
\hline Norway & 6.6 & 6.6 & 6.8 & 5.9 & 7.2 & 7.5 & 7.2 & 7.4 & 8.1 & 8.8 & 9.7 & 10.2 & 10.5 & 9.8 & 10.9 \\
\hline Poland & 8.7 & 11.0 & 11.9 & 10.9 & 13.2 & 15.4 & 14.6 & 16.8 & 18.3 & 8.8 & 7.9 & 8.3 & 9.1 & 7.5 & 6.8 \\
\hline Portugal & 12.0 & 12.7 & 12.7 & 11.3 & 12.5 & 11.0 & 7.5 & 8.6 & 8.9 & 10.1 & 10.1 & 9.9 & 10.2 & 9.7 & 10.3 \\
\hline Slovak Republic & 0.5 & 2.4 & 3.6 & 4.6 & 6.2 & 7.2 & 8.2 & 9.4 & 9.7 & 10.4 & 10.2 & 11.1 & 11.8 & 11.7 & 12.6 \\
\hline Slovenia & 2.2 & 2.8 & 2.9 & 3.1 & 4.0 & 4.8 & 5.0 & 5.2 & 5.3 & 5.6 & 5.7 & 5.7 & 5.7 & 5.6 & 6.0 \\
\hline Spain & 7.1 & 7.3 & 8.0 & 7.0 & 7.9 & 7.8 & 7.8 & 8.3 & 9.0 & 9.6 & 9.6 & 9.5 & 9.4 & 8.8 & 9.5 \\
\hline Sweden & 8.5 & 8.6 & 8.1 & 6.9 & 7.8 & 9.0 & 8.8 & 10.1 & 9.2 & 9.2 & 8.8 & 4.2 & 4.1 & 3.9 & 4.1 \\
\hline Switzerland & 106.6 & 108.0 & 105.1 & 89.7 & 101.6 & 102.0 & 100.7 & 107.4 & 112.9 & 119.6 & 120.5 & 124.8 & 133.7 & 127.4 & 141.1 \\
\hline Turkey & 0.6 & 0.7 & 1.2 & 1.4 & 2.2 & 2.2 & 3.8 & 3.4 & 4.2 & 4.7 & 4.6 & 4.8 & 2.6 & 2.5 & 3.0 \\
\hline United Kingdom & 71.7 & 76.3 & 73.4 & 61.3 & 73.1 & 81.2 & 87.8 & 94.6 & 96.9 & 96.7 & 97.6 & 107.6 & 108.3 & 104.5 & 123.3 \\
\hline United States & 74.4 & 76.2 & 77.3 & 59.1 & 69.4 & 73.8 & 71.2 & 74.9 & 81.4 & 81.6 & 77.5 & 79.3 & 85.5 & 78.9 & 87.5 \\
\hline
\end{tabular}

* 2019 data is preliminary.

Source: OECD (2020), Pension funds' assets (indicator). doi: 10.1787/d66f4f9f-en (Accessed on 29 October 2020) Data are collected from national pension authorities within the framework of the OECD Global Pension Statistics (GPS) project. Data covers all funded plans where assets are accumulated in pension funds, through pension insurance contracts or other vehicles. These plans may be publicly or privately administered, mandatory or voluntary, occupational or personal, for public or private-sector workers. Employers' book reserves are also in the scope. Data for 2019 refer to the end of 2019, except for: Australia where data refer to June 2019; Canada (pension funds) and the United States (individual retirement accounts) where data refer to end Q3-2019; Canada (other than pension funds), Finland, Mexico (occupational plans), Poland (other than pension funds) and Sweden where data refer to 2018. Data on pension funds refer to: mandatory plans in Estonia, earnings-related pension companies and funds in Finland, PERCO plans in France (as no data available yet on the newly created FRPS pension vehicle), Pensionskassen and Pensionsfonds supervised by BaFin in Germany, occupational retirement pension savings in Korea, voluntary plans in Latvia, personal plans in Turkey. 
Some countries invest large amounts whereas others started to increase over time. Countries like the Netherlands, Australia, Iceland and Switzerland are on one end of the spectrum where pension fund assets are more than the GDP. On the other side of the spectrum, countries such as France, Greece, Latvia have pension assets that are less than or around 1 percent of their GDP. Chile seems to provide an interesting analysis as a country that went through pension reform during the 1980s, most recently are 80 percent of GDP.

It is important to analyze the need for pension funds as a tool to manage the needs of retirees. According to the most recent OECD data on pension spending by countries varies as shown in Figure 1, on the one side of the spectrum Italy and Greece's pension spending is more then 16 percent of their GDP and Columbia, Iceland and Mexicos' public pension spending are less than 3 percent of their GDP. The OECD average is around 8 percent of GDP and Turkey's spending is very close to the OECD average.

Figure 1: Public Pension Spending as a percent of GDP, 2017 or Latest Available

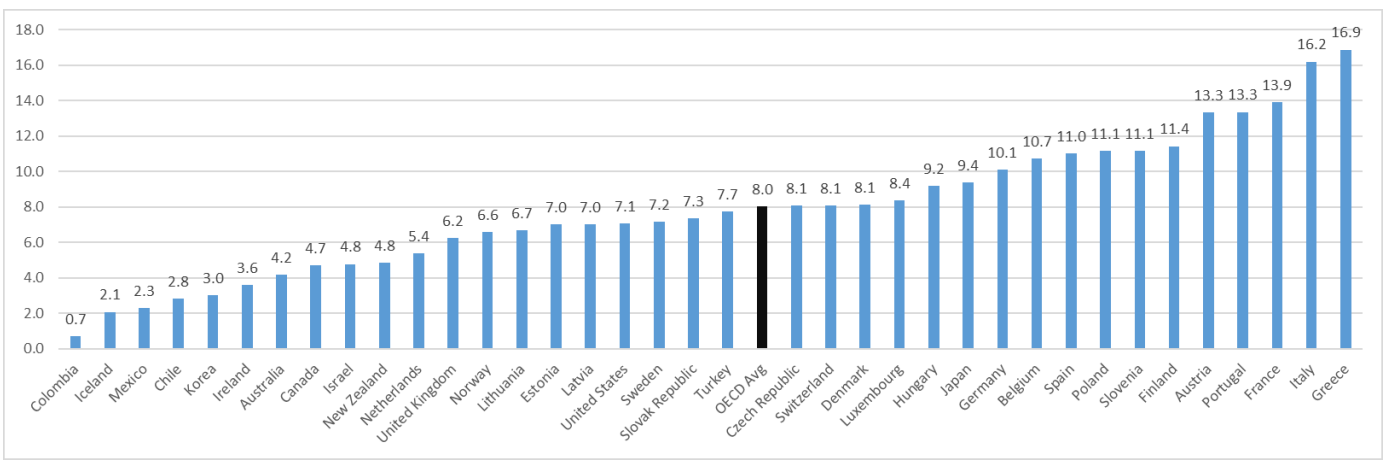

Source: OECD (2020), Pension spending (indicator). Doi: 10.1787/a041f4ef-en (Accessed on 29 October 2020) Pension spending is defined as all cash expenditures (including lump-sum payments) on old-age and survivor pensions. Old-age cash benefits provide an income for persons retired from the labor market or guarantee incomes when a person has reached a 'standard' pensionable age or fulfilled the necessary contributory requirements. This category also includes early retirement pensions: pensions paid before the beneficiary has reached the 'standard' pensionable age relevant to the program. It excludes programs concerning early retirement for labor market reasons. Old-age pensions include supplements for dependents paid to old-age pensioners with dependents under old-age cash benefits. Old age also includes social expenditure on services for the elderly people, services such as day care and rehabilitation services, home-help services and other benefits in kind. It also includes expenditure on the provision of residential care in an institution. This indicator is measured in percentage of GDP broken down by public and private sector. Private pension spending includes payments made to private pension plan members, or dependents after retirement and covers persons working in both the public and private sectors.

In order to decrease the pressure on public finances and raise the overall level of benefits that the retirees will receive, many countries have recently reformed their retirement systems; and many introduced supplementary pensions. Typically, these supplementary plans take the form of funded, DC pensions, managed by private institutions, pension funds (OECD, 2018). Pension funds are 
considered to be large and important institutional investors and invest in many assets such as bank deposits, government and private paper and stocks. Private Pension System is supplementary (complementary) to the existing mandatory state pension plans; and it is intended to be voluntary (CMB, 2020) ${ }^{1}$. As of 2015, OECD (2017) reports an improvement in public finances which resulted in an ease of pressure to reform pension systems. As a result, the pace of pension reforms in OECD countries has slowed down; and reforms have been less widespread on average (OECD, 2017).

During the late 1990s, when the pension reform discussion was quite relevant, the World Bank (1994) was in favor of reforming the pension systems suggesting that in order to optimize savings allocations, a multipillar pension system with a defined contribution arm would be ideal. Others disagreed (Orszag and Stiglitz, 1999). As for the recent wave of pension system structural reforms, the first country to reform their pension system was Chile. In 1981, the country reformed its pension system by introducing a DC pension system. Since then, other countries have also followed suit in reforming their pension systems. Many Latin American countries followed Chile's example and adopted similar reforms. These countries maintained a mixed system of both public and private pensions. In addition, transition economies, such as Hungary, Kazakhstan, Lithuania, Poland, and Slovakia also adopted pension reforms. Developed countries such as the UK moved towards a multi-pillar pension system; and Sweden modified its pension system from a pay-as-you-go DB system towards a second pillar system with a DC plan. The U.S. is also considering making reforms to its pension system. (Raddatz and Schmukler 2008).

It is argued that one key motivation for countries to reform their pension systems has been the expectation that these pension funds would also play a role in the development of capital markets, increasing private sector savings, and reducing the cost of capital for corporations, to achieve more developed and market oriented financial systems. Since pensioners save for the long run, pension funds (unlike retail investors) are expected to be able to provide long-term financing to domestic corporations (fundamentally), as well as governments (Raddatz and Schmukler 2008). In addition, pensioners provide consistent and long-term flow of funds to pension funds, enabling these funds to be a stable source of capital, which can be used to increase the investor base in many financial assets. Importantly, since the investments are for long-term, this gives stability to the financial system. It is also believed that pension funds professionally manage asset allocation and hence, should be able to diversify risk appropriately. They are also regulated and are expected to allocate a big portion of their investment capital in their domestic markets. As a result, these pension funds, compared to other institutional investors, are assumed to contribute to the development of domestic capital markets (Raddatz and Schmukler 2008).

\section{Turkish Pension System}

Turkey has one of the most generous social security systems among OECD countries (Rudolph 2019). Social security transfers from the state reached above 6 percent of GDP in 2018; and is likely to increase in the future. These transfers to the social security institution represent around 40 percent of the total annual expenditures. It is also important to note that Turkey's population is relatively

1 In accordance with Turkish Individual Retirement Law, Article 1. Furthermore, voluntary characteristic of the private pension system is also mentioned on Brief Guide on Pension Mutual Funds by CMB. 
young, and despite this fact, pension expenditures are quite high (OECD average for 2017 is 7.5 percent). Before the reform, Turkey, similar to Chile, had a mature, expensive pension system and unfunded liabilities (Corbo, and Schmidt-Hebbel, 2003).

Figure 2: Budgetary Transfers to the Social Security Institution (1994 - 2018)

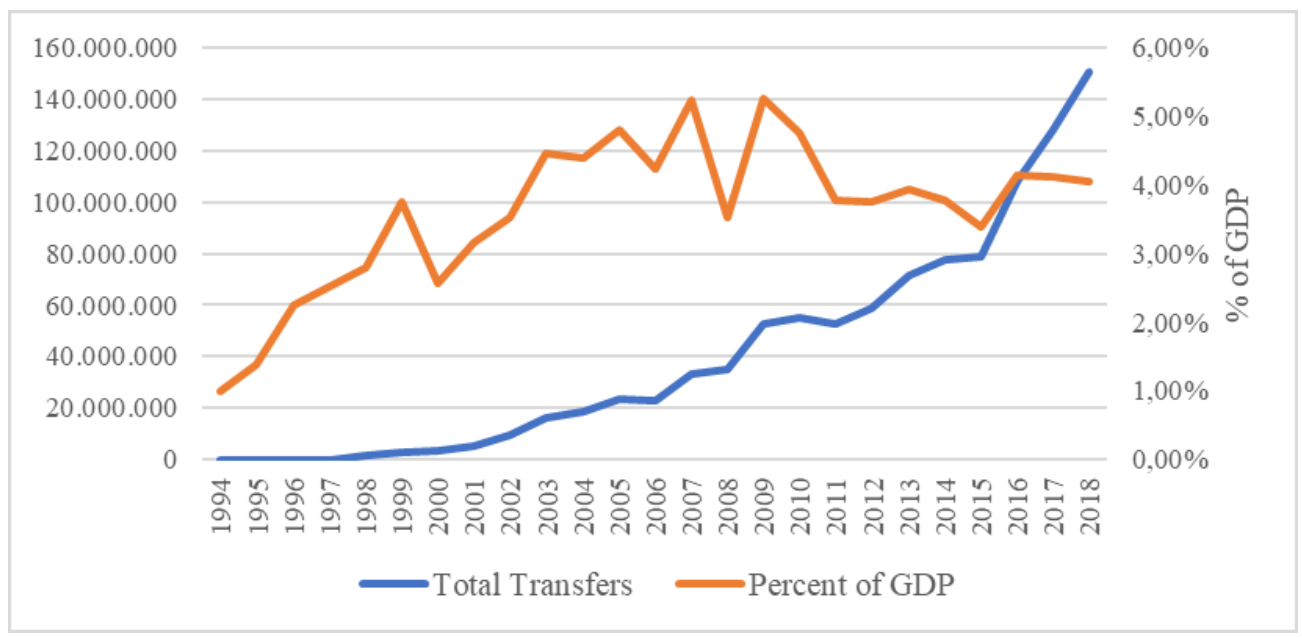

Source: Social Security Institution (http://www.sgk.gov.tr/wps/portal/sgk/tr/kurumsal/istatistik/aylik_istatistik_bilgileri) accessed on October 14, 2019.

The Turkish national pension system was mainly initiated after the Second World War. At that time, the Turkish social security system was made up of three separate social security institutions: Sosyal Sigortalar Kurumu (SSK), covering private and public sector workers; Emekli Sandiği (ES), covering civil servants; and Bă̆-Kur, covering self-employed workers and farmers. The deficits created by these programs over time required increasingly large transfers from the general budget, showing a need for pension reform. The first reform, in 1999, led to a temporary fall in the size of the deficits in the SSK and Băg-Kur systems. However, they subsequently started to rise again due to a combination of discretionary increases in the pension level and shrinkage of the premium base. In 2006, these three institutions were merged under Social Security Institution (SGK), which offers equal social benefits for workers regardless of their employment type (Brook and Whitehouse 2006; SGK, 2020).

Using the terminology of the World Bank's “three-pillar” classification (World Bank, 1994), where there is "a publicly managed system with mandatory participation and the limited goal of reducing poverty among the old [first pillar]; a privately managed mandatory savings system [second pillar]; and voluntary savings [third pillar]," Peksevim and Akgiray (2019) classify the current Turkish pension system into three pillars: i) mandatory pay as you go ("PAYG") public pension system, ii) occupational (mostly defined benefit (DB)-type) pension plans, and iii) the voluntary private pension system with fully-funded defined contribution (DC) schemes (OECD, 2005). ${ }^{2}$ 
The first pillar of the Turkish pension system is the PAYG social security program, which covers employees' old-age pension benefits and other social protection needs such as health care, survivorship, disability, work-related accidents and occupational diseases, unemployment, and life insurance. Under the social security system (Social Security Institution (SGK), which offers equal social benefits for workers regardless of their employment type), the state pension has an earnings-related defined-benefit pension scheme, supported by a means-tested safety net and a flat-rate pension. Currently, the minimum retirement ages are set at 58 for women and 60 for men, to be raised gradually to age 65 by 2048 for both genders. In order to become eligible for old-age pension benefits, employees have to complete at least 7,200 days of contribution period in the system. (Peksevim and Akgiray 2019).

As of year-end 2017, the Social Security System covered around 70 percent of the working population (Social Security Statistics and Labor Force Statistics from the World Bank). Moreover, the first pillar of the Turkish pension system provides a net replacement rate (ratio of net retirement income to net pre-retirement earnings) of about $102 \%$, the highest ratio among the OECD and the EU countries, after Croatia. Despite relatively high coverage and contribution rates, the Turkish social security system has large and growing budget deficits, which are partially funded by the state (Figure 2, Peksevim and Akgiray 2019).

The second pillar of the Turkish pension system mainly consists of two mandatory occupational saving schemes: OYAK and TTK plans. OYAK has been established to provide pension and other social benefits for military personnel, and TTK pension plan covers employees of the state-owned coal mining companies. In addition to these two, there are about 250 voluntary occupational pension schemes in the second pillar of Turkish pension system, and most are small in size and coverage (Peksevim and Akgiray 2019). According to other definitions used in the industry, the second pillar is also defined to cover workplace pensions with auto enrollment, which started in 2017 (Anadolu Hayat, 2019).

The third pillar, a voluntary private pension system (BES) was first introduced in Turkey in 2001 (but went into effect in 2003). The Turkish private pension system is partly a voluntary, fully-funded DC pension scheme. The main objectives of introducing the third pillar pension were to increase domestic savings rates, enhance the welfare of retirees, and ease the financial burden of the social security system on the Turkish government in order to increase employment by generating long term resources and contribute to economic development (Peksevim and Akgiray 2019).

Substituting deductible contributions with government matching contributions may increase participation in retirement savings plans. For example, in Turkey, participation in pension plans was initially encouraged through tax-deductible contributions. In order to make the system more inclusive and boost savings, tax relief on contributions was replaced by state matching contributions in January 2013. Between 2012 and 2013, the number of new participants increased by 65 percent, suggesting that government matching contributions were more effective in increasing the attractiveness of saving for retirement for some people (OECD 2018).

As part of this change in 2003, the government introduced two additional reforms: i) government matching contributions in 2013, and ii) automatic enrollment reform (AES) in 2017. The 
government matching reform replaces the income tax deductibility of contributions with direct contributions from the state, amounting to $25 \%$ of employee contribution (up to $25 \%$ of the annual minimum wage). This revision was effective in that the size of pension fund assets almost doubled in three years (Pension Monitoring Center, 2019; Peksevim and Akgiray, 2019).

In Turkey, AES scheme is mandatory for employers and the contribution rate for the employees starts at 3 percent of the salary. The government provides a one-time TRY 1.000 contribution, and $25 \%$ matching contribution subsidy (OECD 2018). AES was devised via a new law that modified the Turkish voluntary funded pension system.

The modification came into effect in January 2017. All employees (public personnel plus private personnel) younger than the age of 45 are automatically enrolled in the AES system, and are assigned to a pension plan. Employees contribute 3 percent of their taxable earnings. If they wish to opt out in writing, they are given permission to opt out of the system after a 2-month enrollment period. This new system is expected to increase 'non-mandatory' coverage significantly, and increase the savings rate to a greater extent. Even though the number of participants in the voluntary private pension system is increasing every year, as shown in Figure 4 below, the overall size of the market as a percentage of GDP is still small compared to other countries. OECD Pension Market in Focus figures indicate that the ratio of total pension fund assets to GDP in Turkey is $2.1 \%$ with a total amount of USD 14.520 million in 2018.

Figure 3: Turkey - Pension Assets as a Percent of GDP

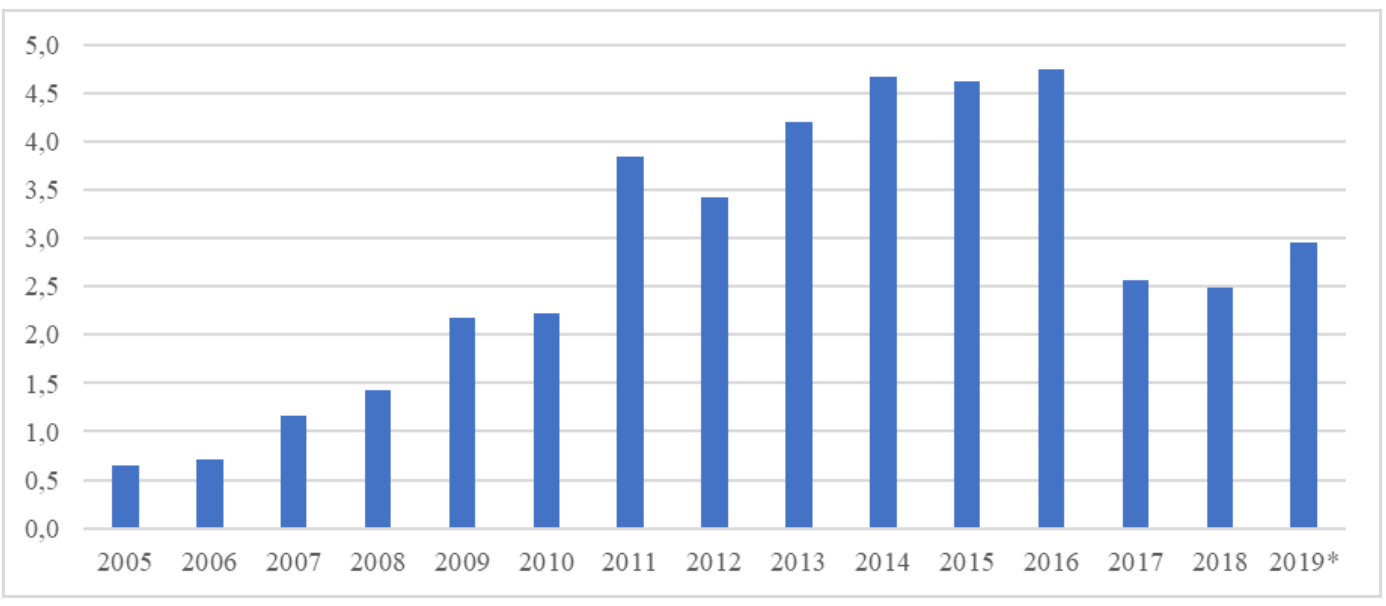

${ }^{\star}$ Preliminary

Source: OECD Database. Note that OECD Pension Assets are defined as all autonomous pension assets (The pool of assets forming an independent legal entity that are bought with the contributions to a pension plan for the exclusive purpose of financing pension plan benefits. The plan/fund members have a legal or beneficial right or some other contractual claim against the assets of the pension fund. Pension funds take the form of either a special purpose entity with legal personality (such as a trust, foundation, or corporate entity) or a legally separated fund without legal personality managed by a dedicated provider (pension fund management company) or other financial institution on behalf of the plan/fund members. 
Figure 4: Pension Assets as a Percent of GDP (OECD)

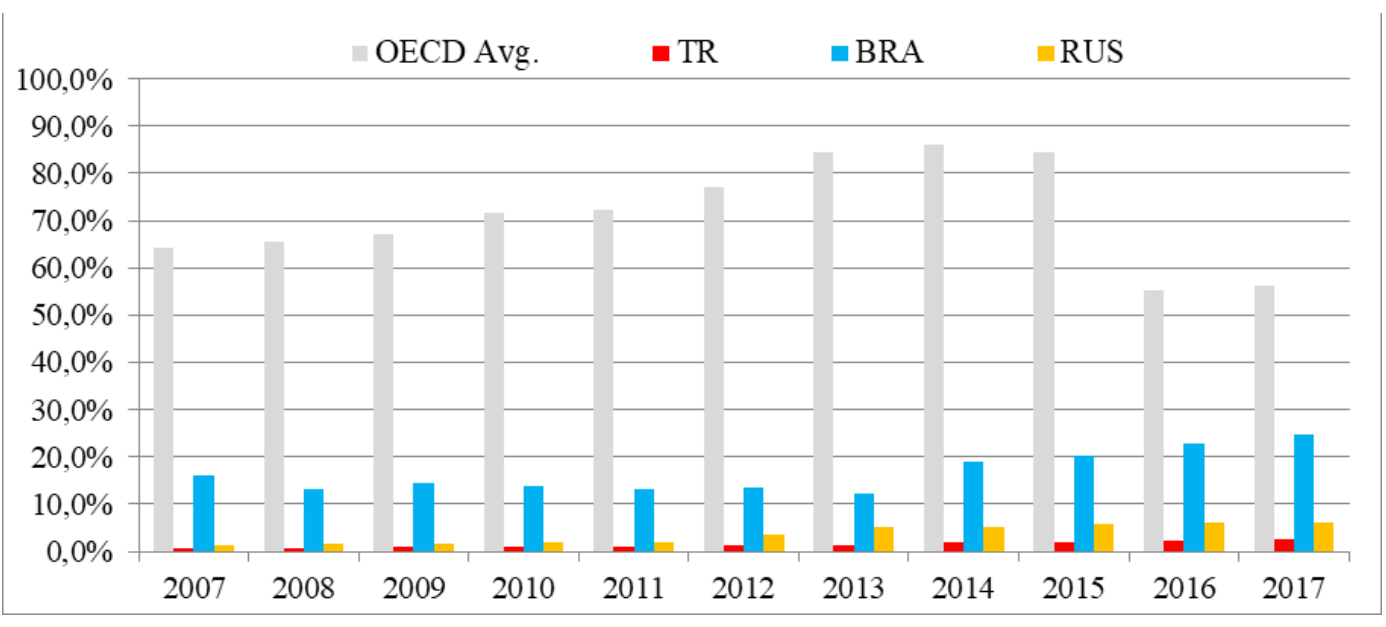

Source: OECD Pension Markets in Focus

Considering preliminary figures of pension fund assets for the year 2018, provided by OECD (Pension Market in Focus), it is apparent that Turkey is behind Brazil and Russia (countries considered similar to Turkey) with respect to the ratio of total pension fund assets to GDP (Turkey 2.1\%; Brazil 12.6\%; and Russia 5.5\%). With 16 years of private pension experience, in Turkey, pension fund assets have been growing remarkably, but the ratio is still quite low in comparison to developed countries and peer group OECD countries.

\section{i. Number of Participants and Types of Firms in Voluntary Pension Funds}

Unlike many other countries, in Turkey, there is a two-tier intermediation structure in the private pension system; pension companies and portfolio management companies. Pension companies are exclusively authorized to sell pension plans and collect contributions from individuals. As they are not permitted to manage funds, they have to choose a portfolio management company to manage members' money. In order to prevent monopolistic concentration and potential governance problems, there are certain rules for choosing fund managers for the pension companies. There were 18 licensed pension companies and 26 portfolio companies managing 408 pension mutual funds (Pension Monitoring Centre, 2017; Turkish Capital Markets Association, 2018). Members are entitled to the full amount of pension benefits when they reach the age of 56, conditional on a minimum 10 years of coverage period.

Despite the fact that the size of assets under management might be small compared to other countries, the voluntary pension fund market is continuously growing. Starting with only 15 thousand participants in 2003, the number reached about 6.9 million at the end of 2019. with total assets under management of approximately TL 102 million except for State Contribution amounts (These values do not include the AES participants). 
On the other hand, as of the end of 2019, the total number of AES participants are nearly 5.4 million with total assets under management TL 8.2 billion.

Figure 5: Total Assets under Management of Voluntary Pension Funds \& Auto Enrollment Funds

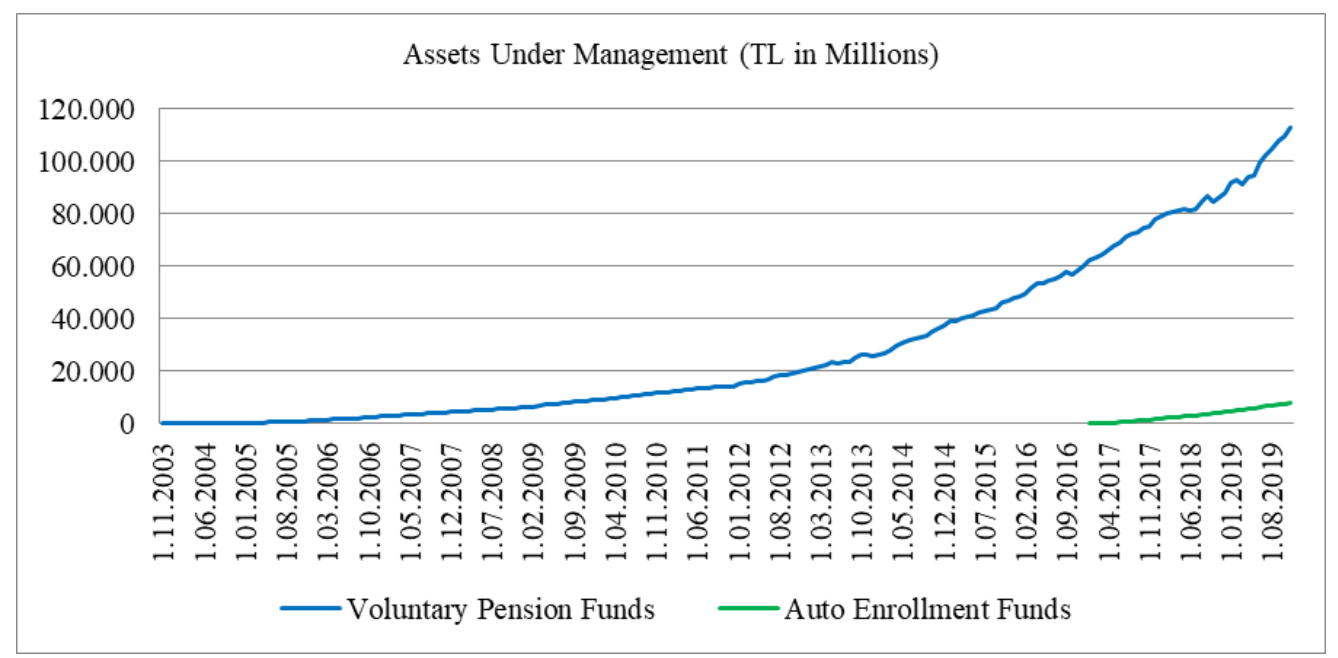

Source: Capital Markets Board of Turkey official website (State Contribution Funds included in the total Voluntary Pension Fund Assets Under Management).

Figure 6: Number of Participants and Number of Firms in Voluntary Pension Funds

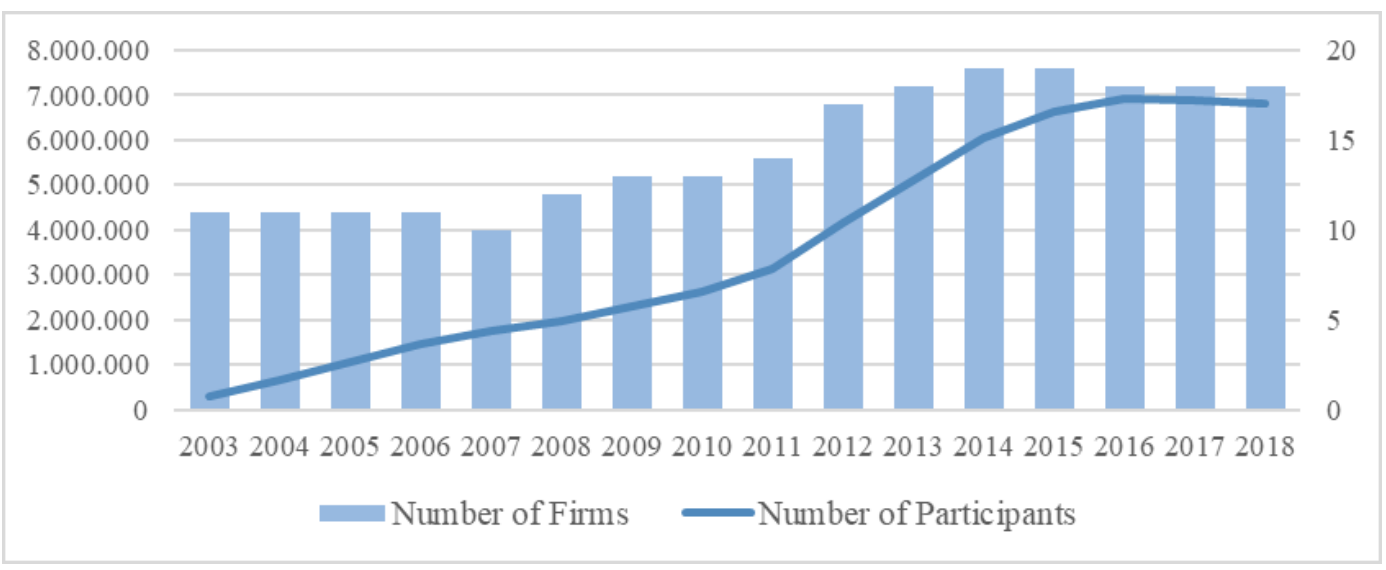

Source: EGM-Turkish Pension Monitoring Authority.

Table 2 compares the voluntary pension plan coverage in selected OECD countries as of 2018. In the table, 'Personal' is akin to 'Voluntary Private Pension Plans'. 
Table 2: Voluntary Pension Plan Coverage

\begin{tabular}{|c|c|c|c|}
\hline \multicolumn{4}{|c|}{ Active members as a percentage of the working-age population (15-64 years) } \\
\hline & Occupational & Personal & Total \\
\hline Austria & 13.9 & 18 & .. \\
\hline Belgium & 59.6 & .. & .. \\
\hline Canada & 26.3 & 25.2 & .. \\
\hline Czech Republic & $\mathrm{x}$ & 52.6 & 52.6 \\
\hline Denmark & $\mathrm{x}$ & 18 & 18 \\
\hline Estonia & $\mathrm{x}$ & 12.3 & 12.3 \\
\hline Finland & 6.6 & 19 & 25.6 \\
\hline France & 24.5 & 5.7 & .. \\
\hline Germany & 57 & 33.8 & 70.4 \\
\hline Greece & 1.3 & .. & .. \\
\hline Hungary & .. & 18.4 & .. \\
\hline Iceland & $\mathrm{x}$ & 45.2 & 45.2 \\
\hline Ireland & 38.3 & 12.6 & 46.7 \\
\hline Italy & 9.2 & 11.5 & 20 \\
\hline Japan & 45.4 & 13.4 & 50.8 \\
\hline Korea & $\mathrm{x}$ & 24 & 24 \\
\hline Latvia & 0.3 & 11.4 & .. \\
\hline Lithuania &.. & .. & 69.5 \\
\hline Luxembourg & 5.1 & .. & .. \\
\hline Mexico & 1.7 & .. & .. \\
\hline Netherlands & $\mathrm{x}$ & 28.3 & 28.3 \\
\hline New Zealand & 6.8 & 74.8 & .. \\
\hline Norway &.. & 26.7 & .. \\
\hline Poland & 1.6 & 66.6 &.. \\
\hline Portugal & 2.5 & $14.7-17.2$ & 17.2 \\
\hline Slovak Republic & $\mathrm{x}$ & 19 & 19 \\
\hline Slovenia & 7 & .. & 37.8 \\
\hline Spain & .. & .. & 26.1 \\
\hline Sweden & $\mathrm{X}$ & 24.2 & 24.2 \\
\hline Turkey & 1 & 13.9 & .. \\
\hline United Kingdom & .. & .. & 43 \\
\hline United States & 40.8 & 19.3 & .. \\
\hline
\end{tabular}

Source: OECD Pension Markets in Focus 2018 (Lithuania and Spain); ASF (Portugal occupational plan coverage), Instituto Nacional de Estatística (Portugal personal plan coverage), OECD Pensions at a Glance 2017 (all other countries). DOI:https://doi.org/10.1787/cb1c3686-en. Note: ".." = Not available; "x" = Not applicable. Countries were included in the table if they had a voluntary pension system (personal, occupational or both) and data was available for those countries. Coverage results for Portugal are an approximation partially based on survey data (Instituto Nacional de Estatística, 2013[3]), since administrative data for personal pension plans is only available at an account level and cannot be aggregated to the individual level. Data for Portugal's occupational plan coverage is based on administrative data provided by the ASF, and the range estimated for personal plan coverage is calculated using the survey data on total pension plan coverage for households minus occupational plan coverage. The estimate for personal plan coverage is expressed as a range to account for the possibility of duplicate cover between personal and occupational plans. As such, the figures for Portugal in this table should be treated as indicative for the purpose of showing country comparisons only. Coverage rates are provided with respect to the total working-age population (i.e. individuals aged 15 to 64 years old), with the exception of Czech Republic (under 65), Germany (employees aged 25 to 64), Iceland (citizens and foreign workers in Iceland between 16 and 64), Ireland (workers aged between 20 and 69), New Zealand (above 17 for personal plans), Sweden (income earners aged 20 to 64). In most cases, data refer to 2016, with the exception of Austria (2012), Belgium (2013), Canada (2015), France (2015), Germany (2015), Greece (2014), Korea (2011), Lithuania (2017), Netherlands (2010), New Zealand (2014 for occupational and 2016 for personal), Portugal (2017), Spain (2014), Sweden (2015), United Kingdom (2015/16) and United States (2013). However, please refer to OECD Pensions at a Glance 2017 and OECD Pension Markets in Focus 2018 for more country-specific notes. 
In Turkey, the voluntary private pension plans can only be operated by retirement firms (life and pension funds). The number of pension companies increased from 11 firms in 2003 to 18 firms in 2018. As of end of 2019, there were 16 companies (considering 'Allianz Hayat ve Emeklilik' and 'Allianz Yaşam ve Emeklilik' as a single firm). The market is fairly concentrated among the top players. Top four companies with their market share ${ }^{3}$ (proxied by AuM they managed) were as follows, according to the latest figures as of July 2019: Allianz Group (Allianz Hayat + Allianz Yaşam) 17\%; Anadolu Hayat Emeklilik 18.5\%; Avivasa Emeklilik ve Hayat 19.2\%; and Garanti Emeklilik ve Hayat 14.3\%. Assets under management (AuM) of top four companies composed 70 percent of total AuM for the industry.

It should be noted that total AuM of publicly held companies that offer voluntary pension fund products is about $18 \%$ of the industry (Halk Emeklilik 4.6\%; Vakıf Emeklilik 8.2\%; and Ziraat Emeklilik 5.1\%). On 24 August 2020, these 3 state-run pension companies were merged under the name of 'Türkiye Emeklilik ve Hayat'.

\section{ii. Types of Products that are Offered and Investment in Capital Markets}

By regulation, the markets and investment tools that pension funds use are specifically determined, and monitored by the Capital Markets Board. Since 2016, pension funds -by way of professional portfolio managers of Asset Management Companies - have been allowed to invest in the following assets as shown in Table 3.

Table 3: Maximum Rate of Assets to Portfolio Value (\%) ${ }^{4}$

\begin{tabular}{lc} 
Assets and Transactions & $\begin{array}{c}\text { Maximum Rate of Assets \& Transactions to Portfo- } \\
\text { lio Value) (\%) }\end{array}$ \\
Stocks & 100 \\
Borrowing Instruments (Bonds - Public \& Private) & 100 \\
Mutual fund participation certificate and Investment trust certificate & 20 \\
Reverse Repo & 10 \\
Takasbank money market transactions & 10 \\
Mortgage and asset guaranteed security. & 100 \\
Mortgage and asset backed securities & 100 \\
Loan participation note & 10 \\
Structured investment vehicle & 10 \\
Warrant / Certificates & 15 \\
Lease certificate & 100 \\
Deposits / Participation Accounts (Profit and Loss Accounts) & 25 \\
Securities lending & 50 \\
Precious metals lending & 50 \\
Precious metals lending certificate & 50 \\
\hline
\end{tabular}

Source: Guide published by Capital Markets Board (CMB) upon resolution 2016/7; Capital Market Board Official Gazette, no: 28586 (13 March 2013) (articles 5, 6, 12).

3 Excluding State Contribution Funds and AES-Pension Funds.

4 This table is not applicable for every single fund type, that is to say every single pension fund (type) has its own max. rate structure (Maximum Rate of Assets \& Transactions to Portfolio Value \%). Main legal (binding for pension companies) document covering detailed rules \& principles for pension fund types, titles and portfolio limits is 'the Regulation on establishment and activities of pension funds'. 
In terms of asset allocation, Figure 7 provides information on the asset allocation of all pension funds in Turkey (as of the end of October, 2020) as compared to the OECD average asset allocation of all pension assets.

Figure 7: Pension Funds Average Asset Classification \% (October 2020)

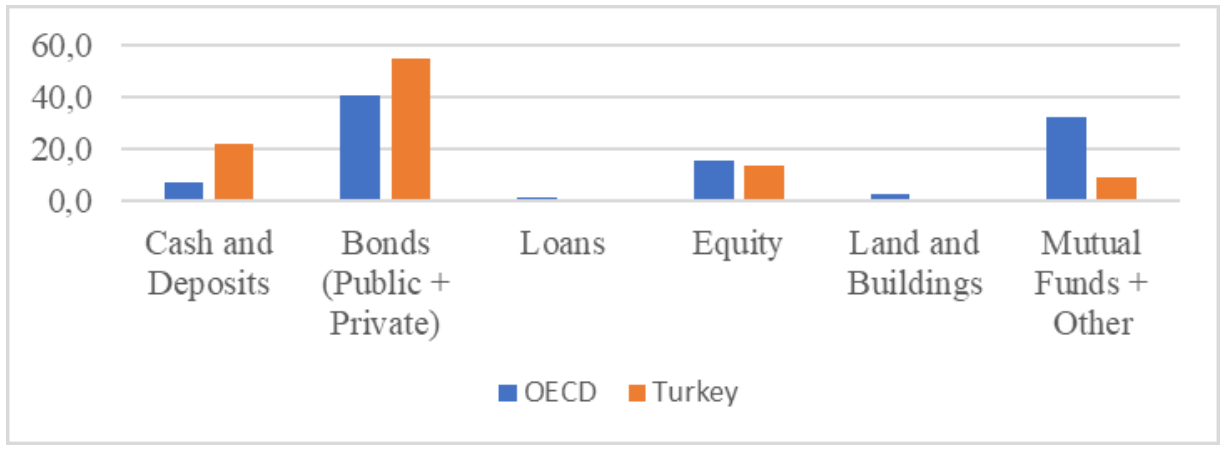

Source: OECD (2020). Pension spending (indicator). Funded Pension Statistics (Accessed on 29 O ct ob er 2020). OECD and Turkey have similar structure in that a great deal of amount is invested in public and private debt instruments, namely bills and bonds. Also, regarding the ratio of assets invested in equities, they have similar percentage figures. On the other hand, as far as cash \& deposits and other assets (especially mutual funds) are concerned, there are considerable differences (as of October 2020).

Figure 8: Historical Consolidated Portfolio Structure of Pension Funds in Turkey

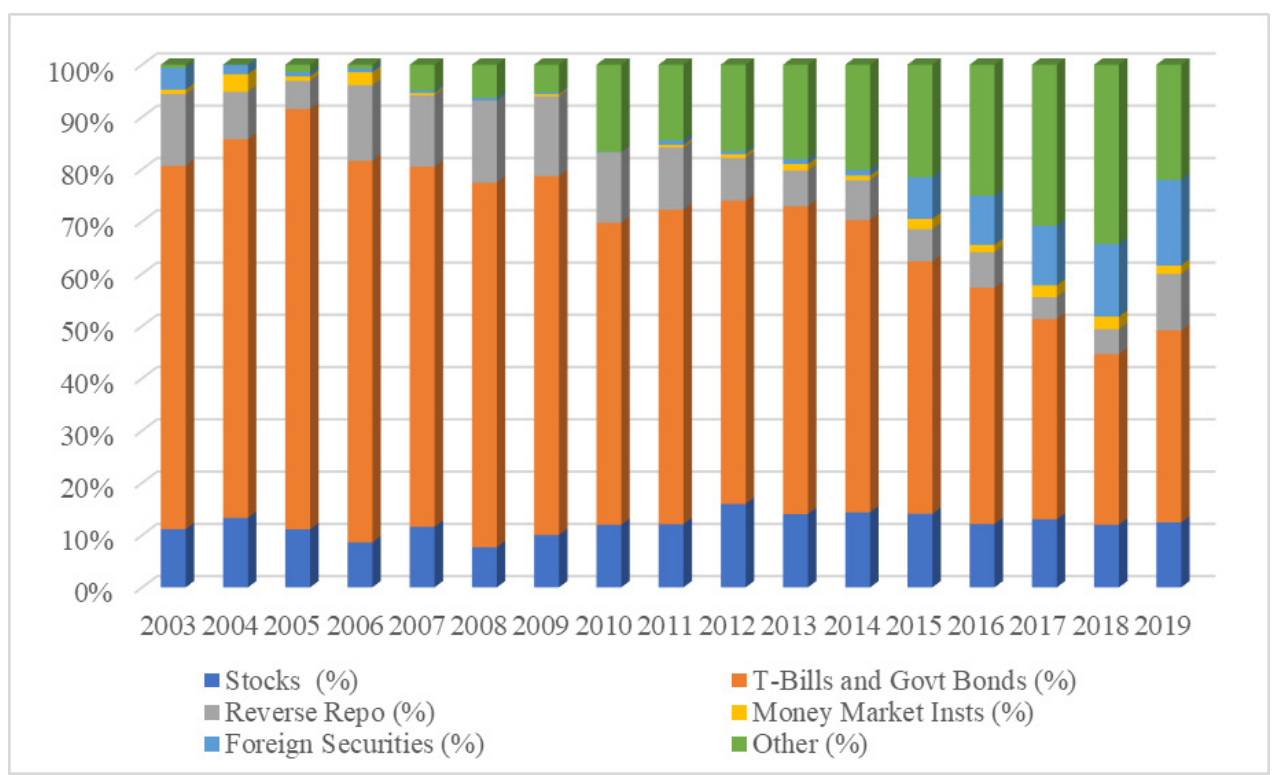

Source: Authors' calculations from Capital Markets Board Monthly Bulletins. 
Figure 8 provides a more detailed picture of the actual investment pattern of pension funds as a percentage of total assets. Equities consistently represent about 10 percent of total assets. Throughout the years, total portfolio of voluntary pension funds (total 'AuM') has been heavily composed of debt securities (T-Bills and Government Bonds). However, after 2012, the share of debt instruments in total AuM declined steadily while the share of other assets (represented by 'other' in Figure) went up significantly, which could be attributed to the introduction of new investment tools (new asset type) in the financial investment environment \& developing capital markets in Turkey. As far as foreign securities are concerned, they started to have a remarkable share in total AuM after 2015.

In accordance with Pension Fund Guide (EYF Rehber) by Capital Markets Board, the companies offer products (plans of pension funds) to clients (contributors). Plans are made up of pension funds. Pension fund types are as follows:

- Stock Funds - invest at least 80 percent of its portfolio into domestic or foreign stocks.

- Borrowing Instruments Funds - need to invest at least 80 percent of its portfolio into domestic or foreign public or private sector debt securities or reverse repos.

- Participation Funds (Non-Interest Funds) - need to invest all of its portfolio into lease certificates, precious metals, participation accounts, and other financial instruments that are not dependent on interest.

- Mixed Funds - need to invest at least 20 percent of the fund's portfolio into stocks, bonds, precious metals and lease certificates (total fund portfolio must consist of at least 80 percent of these instruments, and at least two must be selected).

- Money Market Funds - need to invest in liquid money market \& capital market instruments with maturity less than 184 days (portfolio should not exceed an average maturity of 45 days)

- Precious Metals Funds - need to invest at least 80 percent of the fund portfolio in gold \& other precious metals and also money \& capital market tools based on these.

- Index Funds - need to invest at least 80 percent of the fund in assets within the framework of indices approved by $\mathrm{CMB}$.

- Fund Basket Funds - need to invest at least 80 percent of its portfolio in mutual funds, securities mutual funds ('borsa yatırm fonu'), foreign mutual funds.

- State Contribution Funds - need to invest heavily in government debt instruments. This is a compulsory fund established for state contributions.

- Variable (Flexible) Funds - Those funds that are not classified under the above-mentioned categories (in terms of portfolio constraints) are considered variable funds.

- Standard Funds - These are compulsory funds for companies to set up. The fund is managed in accordance with rules specified by the Ministry of Treasury and Finance. The fund heavily invests in government debt instruments.

-Life Cycle Funds - There is a need to devise an investment strategy considering specific features of the clients such as expected retirement date, risk appetite and age. 


\section{iii. Regulatory Bodies}

Capital Markets Board of Turkey (CMB), which was established in 1982, regulates the establishment, operations of pension companies by regulation. CMB also regulates the structure of fund portfolio. In addition to $\mathrm{CMB}$, the Ministry of Treasury and Finance (issues regulatory documents especially about state contribution) and Pension Monitoring Authority are the main regulatory bodies.

\section{Literature}

The literature on pension funds looked at a few main strands. The first main area is whether pension funds in turn facilitate capital market development. Especially after the recent reforms. Bodie (1990) suggests that pension funds have played a critical role in the evolution of the markets for debt and equity securities and their derivatives in the U.S. over the last 15 years. Kim (2008) analyzes the impact of pension funds on capital market development as well. In the study, stock market capitalization is used as proxy for capital market development, and bond market capitalization is used as proxy for bond market. The study covers 21 OECD countries for the period 1991-2003. Findings suggest that there needs to be a critical mass for pension reforms to result in the development of capital markets; and a secured market mechanism with respect to the management of pension plans are necessary for pension funds to contribute to the capital market development (externality hypothesis). This is supported in four Anglo-Saxon countries, but is not observed in the 11 European countries and Japan.

With the introduction of pension reforms during the 1990s in Chile, and then observing the spillover of these reforms to other countries (Weyland, 2005), many empirical studies tried to find evidence of linkages between pension fund reforms and capital markets. Walker and Lefort (2002) support findings of institutional capital, an increase in adaptive legal framework, increased specialization, transparency and integrity, increased financial innovation, and better corporate governance.

Still, whether pension systems help with capital market development is a point of debate in the literature. Some authors argue that pension funds help with capital market development by increasing demand for investment instruments, and also increasing the depth related to liquidity and volume of equity and debt markets. In addition, since pension funds are long-term investors, and they are considered institutional investors, they demand better corporate governance (Catalán, 2004; Catalán et al., 2000). Pension funds also add to the liquidity of these markets through their trading activity (Davis 2003, Vittas, 1995, 1999; Corbo and Schmidt-Hebbel, 2003). Similarly, Liang and Bing (2010) focus on the UK pension system; and using various models confirm that pension fund growth and financial market development are positively related. On another aspect, Gillan and Starks (2000) focus on two major U.S. pension funds, and conclude that their involvement in companies improves corporate governance practices. Other cross country studies finding positive linkages between pension funds and capital market developments include $\mathrm{Hu}$ (2012), covering 10 Asian and Pacific countries; Raisa (2012), covering EU - 15 countries; Sun and Hu (2014), covering 55 countries; Meng and Pfau (2010), focusing on 34 developed and emerging market countries, and separately looking at stock and bond market effects; and Niggemann and Rocholl (2010), covering 57 countries. 
Hryckiewicz (2009) focusing on eight Central and Eastern European (CEE) countries for the period 1995-2006, finds evidence to support the contribution of the pension fund reforms within CEE countries. Enache, Miloş, and Miloş (2015) maintain that empirical studies that they conducted for the period 2001-2010 confirm their hypothesis that the accumulation of pension fund assets is beneficial for the development of the financial market, increasing its capitalization again using data from Central and Eastern European countries.

Others disagree and also argue that pension funds are not optimally investing the savings of individuals (Berstein and Chumacero, 2006) or do not find a link between capital market development and pension fund reforms (Raddatz and Schmuckler, 2008). For instance, Samwick (2000) does not find any evidence for countries that switch to defined contribution plans with higher savings rates after they implement the reforms using time series data. Also, Chile seems to be the outlier with establishing higher savings rates although cross sectional analysis finds lower savings rates for countries that use pay-as-you-go systems. Raddatz and Schmuckler (2008) investigate the relation between pension funds and capital market development in Chile for the period 1995-2005. The authors argue that "although pension funds may have contributed to the development of certain primary markets, these patterns do not seem fully consistent with the initial expectations that pension funds would be a dynamic force driving the overall development of capital markets. The results do not appear to be explained by regulatory restrictions".

Looking at the question of pension funds' effects on equity markets from the volatility side, Thomas, Spataro and Mathew (2014), using 34 OECD countries during the period 2000-2010, conclude that a negative relation exists between pension funds' stock holdings and (stock) market volatility. Impavido, Musalem, and Tressel (2001), focusing on 34 countries, find that growth of pension funds increases competitive pressure for banks; and as a result, banks operate more efficiently.

The second strand looks at pension funds, savings and economic growth. Apilado (1972) in his study investigates whether pension savings represent a substitution for other forms of personal saving and his findings reveal that pension savings do no substitute for other types of personal savings. When we compare this finding with Turkish case, we see similarity in that voluntary pension funds do not substitute for other conventional savings products (deposits, fixed income investments, stocks)

The third area focuses on pension fund performance, their asset allocation decisions and the riskiness of investments. Alestalo and Puttonen (2006) argue that there exists a connection between the liability structure and asset allocation; assets of the pension funds that younger clients predominantly prefer are structured upon stocks (shares prevail in the fund portfolio), on the other hand portfolios of assets of (comparatively more) mature funds are mostly made up of fixed income instruments (like bonds, deposits). Blake et al. (1999) making use of a data set on more than 300 U.K. pension funds' asset holdings study the relation between asset allocation dynamics and pension fund performance and maintain that strategic asset allocation explains most of the time series variation in portfolio returns, in addition this finding they also contend that market timing and asset selection are less significant as far as fund performances are concerned. 
Studies regarding Turkey are limited, but existing studies provide results in line with those conducted for developed countries as well as emerging economies: pension funds positively affect capital market development proxied mostly by stock market as well as bond market development.

With respect to studies focusing on the Turkish pension funds, Bayar (2017) analyzes the impact of individual pension funds on the development of debt securities market and also stock market in Turkey. He argues that, in the long run, the private pension funds had a positive impact on the development of both debt securities market and stock market. Bayar concludes that private pensions may lead to the sustainability of pension system and development of capital markets, and in turn the economic growth. He also has the following conclusion, taking into account the aging population, decline in government revenue and spill-over effects of private pension funds, economies should carry out policies that would increase private pensions' share. Togan-Egrican and Kayhan (2020) find confirming evidence using Turkey stock market and bond market data suggesting that voluntary pension funds are associated positively with various capital market indicators. Sahin et al. (2019) examine the effects of individual pension funds on capital market development in Turkey, using monthly data for the period 2006-2017. Findings indicate that individual pension funds support stock market development in the long term. In spite of that, this relation is not applicable in the short run. Two recent papers by Ertugrul, Gebesoglu, Atasoy (2018) and Ertugrul, Ozorhan (Forthcoming) look at the effect of voluntary private pension funds on overall savings rates in Turkey, and conclude that the private pension system contribute to the overall saving rate. Our contribution to the literature is along the lines of these studies, but we consider many additional market indicators and newly established markets as well as test for confounding factors, using different specifications and control variables. One other study by Gokcen and Yalcın (2015) shows that active investing did not perform better than the passively invested pension funds using data on private Turkish pension industry.

With regards to the pension system, Turkey's cluster among the world as a OECD country is analyzed in Dalkilic's study (2013); the study shows that the countries that resemble Turkey in regard to pension design -by using hierarchical and non-hierarchical method - are Greece, Portugal, Spain, Czech Republic, Slovak Republic, Italy, Korea, Slovenia. Another way of saying, in the paper it is underlined that Turkey resembles these countries from the point of structure of private pension funds (private retirement system).

In Turkey, private pension product as a line of business is provided by life and pension companies in insurance industry, that is to say there is no Turkish Insurance company selling solely pension product. Life and pension products (together with personal accident) are provided by life \& pension insurance companies provided that they are found eligible and given the authority (license) to sell pension products (pension plans). Given this, literature upon life insurance companies deserves to be mentioned here. Apart from the contribution of private pension funds to the capital markets and total savings, the companies (selling pension products in addition to life insurance product) themselves create a significant economic activity in Turkey like other developed and developing industries. As far as this very fact is concerned, Kaya and Kaya (2015:108) while examining firm-specific factors determining the financial performance of life insurance companies in Turkey underlines the fact that financial performances of insurance companies considered as one the most important players (for savings and investment) in the financial system 
affect total insurance industry, in turn whole economy; and that high performance of these firms enable insurance companies to make contribution to economic growth and national wealth level.

\section{Conclusion}

It is of interest to many including policymakers to see whether pension reforms that are conducted in many countries within the last two decades are associated with capital market development. Since Turkey implemented a voluntary private pension system that went into effect in 2003 , we describe the introduction of voluntary private pension funds in Turkey and the developments with respect to the voluntary private pension funds since then.

So far, findings indicate that the reforms on the introduction of voluntary pension funds in Turkey have positive implications for the overall national savings rates and capital market development and also create an extra income for beneficiaries. However, more needs to be done to increase participation.

Despite significant development in the voluntary pension industry with respect to the volume of asset under management, increasing number of participants, there are some issues to be resolved. Although these issues are beyond the scope of this paper, it is necessary to mention them here briefly. Firstly, in order to increase participation, simplified reporting (basic information on returns, comparison with peer group, comparison with fund benchmark, etc.) about the voluntary private pension funds should be provided to participants. Complex, comprehensive text message and reports cause clients to refrain from this product (as an alternative savings/investment tool). Secondly, performance of voluntary pension funds has been an important issue that the industry is faced with. As a matter of fact, when participants compare the short-term return of the funds with other conventional investment tools such as equities, at certain time periods comparatively lower returns of the funds in general have been seriously criticized by participants. In this point, by educating the participants with marketing and presentation tools on the key factors for correct assessment of the comparative returns; only long term returns (5-year, 10-year) can be compared with other saving/investment instruments since pension funds as a saving product has to be treated differently from other products due to its very nature (long-term nature). Thirdly, this line of business is still not profitable in Turkey. Apart from the leading life \& pension companies, most of the companies in this industry suffer from low profitability of voluntary private pension funds as a line of business perhaps due to heavy regulation on asset allocation. This fact poses an obstacle (in a way lack of interest) to investment in this line of business (in the form of human capital, technical tools) by company owners. Pension companies have been faced with decreasing management fees (official limits to maximum rate of fees which is the only income of industry from this line of business) throughout the years. This issue has to be evaluated with the fact that most of income of the life and insurance companies in the industry comes from life (insurance) business but not from pension business.

In addition to these, for all parties of private pension system, which are participants, pension companies and portfolio management companies (PMC) this paper recommends the following actions to be taken in an effort to enhance the current private pension system in Turkey; 
For participants, which are the main party of the system; a legislation that is simpler, constant (not changing frequently) and easily monitored by everyone should be ensured. Furthermore, state incentive (direct state contribution, 25\%) should continue for the participants. In addition, participants should be enabled to choose more pension funds (while choosing funds for their fund basket) with the help of TEFAS-Electronic Fund Trading Platform.

For pension companies, a legislation which is more concise and stable should be ensured in order for these companies not to be faced with the necessity to invest in new operational system (in order to be in line with the continuously changing legal environment), which creates operational cost. Besides, financial literacy should be increased so that more people will be aware of the necessity of private pensions, and in return they will prefer this system for long-term saving.

As far as Portfolio Management Companies are concerned; more competitive (fund management) environment should be ensured in order that fund managers will increase their asset-management abilities, in the final analysis participants will be able to make use of increasing yields. Apart from that, a certain standard should be brought to the publications that only highlight the periods when the performance was not good in the pension funds, which will cause negative and loss of trust in the media.

Considering all these, in Turkey, voluntary private pension funds have turned out to be a pivotal element in increasing total savings and enhancing capital markets \& new products despite some issues. That is to say, voluntary private pension system has a long way to go in Turkey, and the funds will keep on growing in scope and size together with issues/debates upon management fees, return measurement approach.

\section{References}

ALESTALO, Noora, Vesa PUTTONEN. 2006. "Asset Allocation in Finnish pension funds" Journal of Pension Economics and Finance 5 (1):27-44 DOI: https://doi.org/10.1017/S147.474.7205002295.

ANADOLU HAYAT. 2019. https://www.anadoluhayat.com.tr/files/yatirimci-iliskileri/yatirimci-sunumlari/2017/2017-03-31-Investor-Presentation.pdf (Accessed on December 30, 2019).

APILADO, Vincent P. 1972. “Pension Funds, Personal Savings, and Economic Growth” Journal of Risk and Insurance 39 (3):397-404

BAYAR, Yllmaz. 2017. “Individual Pension Funds and Capital Market Development in Turkey” Review of Economic and Business Studies 9 (2): 95-109.

BERSTEIN, Solange M., Romulo A. CHUMACERO. 2006. "Quantifying the Costs of Investment Limits for Chilean Pension Funds.” Fiscal Studies 27(1): 99-123

BLAKE, David, Bruce N. LEHMANN and Allan TIMMERMANN. 1999. "Asset Allocation Dynamics and Pension Fund Performance” The Journal of Business 72(4, October): 429-461

BODIE, Zyi. 1990. "Pension Funds and Financial Innovation." Financial Management

BROOK, Anne-Marie, and Edward WHITEHOUSE. 2006. “The Turkish Pension System Further Reforms to Help Solve the Informality Problem.” OECD Social, Employment and Migration Working Papers 44, OECD Publishing. 
CAPITAL MARKETS BOARD (CMB). 2020. https://www.cmb.gov.tr/Sayfa/AltSayfa/23 (accessed on November 11,2020).

CAPITAL MARKETS BOARD (CMB). 2019. https://www.spk.gov.tr/Sayfa/AltSayfa/286 (accessed on December 3, 2019).

CATALAN, Mario, Gregorio IMPAVIDO and Alberto R. MUSALEM, 2000. "Contractual savings or stock market development - Which leads?” Policy Research Working Paper Series 2421, The World Bank.

CATALAN, Mario.2004. "Pension Funds and Corporate Governance in Developing Countries: What Do We Know and What Do We Need to Know?” Journal of Pension Economics and Finance 3 (2): 197-232. doi:10.1017/S147.474.7204001532.

COMERT, Hasan and Erinc YELDAN. 2018. “A Tale of Three Crises in Turkey: 1994, 2001, and 2008-09.” University of Massachusetts, Amherst, Political Economy Research Center Working Paper No: 465.

CORBO, Vittorio, Klaus SCHMIDT-HEBBEL. 2003. "Macroeconomic Effects of the Pension Reform in Chile." Pension Reforms: Results and Challenges, 241-329. Santiago: International Federation of Pension Fund Administrators.

DALKILIC, Nilufer. 2013. “Özel Emeklilik Fonlarının OECD Ülkelerinde Değerlendirilmesi”, Marmara University Journal of Financial Researches and Studies, 4 (8): 35-53.

DAVIS, Edward. 2003. "Linkages Between Pension Reform and Financial Sector Development." Asian Development Bank.

ENACHE, Cosmin, Laura Raise MILOS, Marius Cristian MILOS. 2015. "Pension reform and capital market development in Central and Eastern European countries." Economic Research. 28.

ERTUGRUL, Hasan Murat, Fulya OZORHON, 2019 (forthcoming). “The Effect of Private Pension Scheme on Savings: A Case Study for Turkey." Borsa Istanbul Review.

ERTUGRUL, Hasan Murat, Pinar Fulya GEBESOGLU, Burak Sencer ATASOY (2018). "Mind The Gap: Turkish Case Study of Policy Change in Private Pension Schemes." Borsa Istanbul Review. 18 (2): 140-149.

GILLAN, Stuart L. and Laura T. STARKS. 2000. "Corporate governance proposals and shareholder activism: The role of institutional investors" Journal of Financial Economics 57 (2, August): 275-305.

GOKCEN, Umut and Atakan YALCIN. 2015. “The case against active pension funds: Evidence from the Turkish Private Pension System." Emerging Markets Review, vol. 23(C): 46-67.

HRYCKIEWICZ, Aneta. 2009. “Pension reform, institutional investors' growth and stock market development in the developing countries: does it function?" NBP Working Papers 67, Narodowy Bank Polski, Economic Research Department.

HU, Yuwei. 2012. "Growth of Asian Pension Assets: Implications for Financial and Capital Markets” Asian Development Bank Institute, Working Paper No: 360.

IMPAVIDO, Gregorio, Alberto R. MUSALEM, \& Alberto R. TRESSEL. 2001. "Contractual savings institutions and banks' stability and efficiency” Policy Research Working Paper Series 2751, The World Bank.

KAYA, Emine Öner, Bekir KAYA. 2015. “Türkiyede Hayat Sigortası Şirketlerinin Finansal Performansını Belirleyen Firmaya Özgü Faktorler: Panel Veri Analizi”, Marmara University Journal of Financial Researches and Studies 7 (12): 93-111.

KIM, Hee-S. 2008. "Spillover Effects of Pension Funds on Capital Markets: The Mechanism and Preconditions" Available at SSRN: https://ssrn.com/abstract=2805804 or http://dx.doi.org/10.2139/ssrn.2805804

LIANG, Ren and Li BING. 2010. "Management of UK Pension Funds and Financial Market Development: 19702008”. IEEE Proceedings. 2010 International Conference. 4. 594 - 598. 10.1109/ICIII.2010.623.

MENG, Channarith and Donald Pfau WADE. 2010. “The Role of Pension Funds in Capital Market Development." GRIPS Discussion Paper. 
NIGGEMANN, Taro and Jörg ROCHOLL. 2010. "Pension Funding and Capital Market Development" SSRN working paper.

OECD (2017), Pensions at a Glance 2017: OECD and G20 Indicators, OECD Publishing, Paris. http://dx.doi. org/10.1787/pension_glance-2017-en

OECD Pensions Outlook 2005.

OECD Pensions Outlook 2018.

OECD Pension Markets in Focus, 2019.

ORSZAG, Peter R. and Joseph E. STIGLITZ,1999. "Rethinking Pension Reform: Ten Myths about Social Security Systems." Presented at the World Bank Conference, "New Ideas About Old Age Security" September 14-15, 1999.

Pension Monitoring Center. 2017. Individual Pension System Progress Report 2017.

Pension Monitoring Center. 2019. https://www.egm.org.tr/auto-enrollment-system-aes/what-is-aes/ (accessed on December 30, 2019).

PEKSEVIM, Seda and Vedat AKGIRAY. 2019. "Reforming the Pension System in Turkey: Comparison of Mandatory and Auto-Enrolment Pension Systems in Selected OECD Countries" OECD.

RAISA, Milos Laura. 2012. "Spillover Effects of Pension Funds On Capital Markets. The Eu-15 Countries Case," Annals - Economy Series, Constantin Brancusi University, Faculty of Economics 4, December, pp. 164-170.

RADDATZ, Claudio and Sergio L. SCHMUKLER. 2008. "Pension Funds and Capital Market Development: How Much Bang for the Buck?” Policy Research Working Paper; No. 4787. Washington, DC: World Bank.

RUDOLPH, Heinz P. 2019. "Pension Funds with Automatic Enrollment Schemes: Lessons for Emerging Economies” Policy Research Working Papers.

SAHIN, Serkan, Zeynel Abidin ÖZDEMİR and Yıldırım Beyazıt ONAL. 2019. “Türkiye’de Bireysel Emeklilik Sisteminin Sermaye Piyasasının Gelişimi Üzerine Etkisi” Dokuz Eylul Universitesi Iktisadi ve Idari Bilimler Dergisi 33 (2): 517-541.

SAMWICK, Andrew. 2000. "Is Pension Reform Conducive to Higher Saving?" The Review of Economics and Statistics 82 (2): 264-272.

SOCIAL SECURITY INSTITUTION (SGK). 2020. http://www.sgk.gov.tr/wps/portal/sgk/tr/kurumsal/kurumumuz/tarihce.

STEWART Fiona, Romain DESPALINS and Inna REMIZOVA. 2014. "Pension Funds, Capital Markets and the Power of Diversification" World Bank, Policy Research Working Paper No: 8136.

SUN, Shouji and Jiye HU. 2014. "The Impact of Pension Systems on Financial Development: An Empirical Study" The Role of Law and Regulation in Sustaining Financial Markets 4, Routledge. http://dx.doi. org/10.2139/ssrn.2481749

THOMAS, Ashok, Luca SPATARO and Nanditha MATHEW. 2014. "Pension funds and stock market volatility: An empirical analysis of OECD countries." Journal of Financial Stability 11 (1): 92-103.

TOGAN EGRICAN, Asli and Fatih KAYHAN. 2020. "Voluntary Private Pension Funds and Capital Market Development." Working paper.

Turkish Capital Markets Association, 2014. “The Handbook of the Turkish Capital Markets.”

VITTAS, Dimitri, 1995. “Sequencing social security, pension, and insurance reform,” Policy Research Working Paper Series 1551, The World Bank.

VITTAS, Dimitri. 1999. “Pension Reform and Financial Markets.” Harvard Institute for International Development, Development Discussion Papers, No: 697. 
WALKER, Eduardo and Fernando LEFORT. 2002. "Pension Reform and Capital Markets: Are There Any (Hard) Links?" Abante, 5 (2):77-149.

WEYLAND, Kurt. 2005. “Theories of Policy Diffusion Lessons from Latin American Pension Reform.” World Politics 57 (2):262 - 295.

THE WORLD BANK. Averting the old-age crisis. Oxford, Oxford University Press, 1994.

THE WORLD BANK DATA (GDP Growth) https://data.worldbank.org/indicator/NY.GDP.MKTP.KD.ZG?locations=TR. 2020 